\begin{abstract}
Iranica
Abstracta Iranica Revue bibliographique pour le domaine irano-aryen

Volume 34-35-36 | 2017

Comptes rendus des publications de 2011-2013
\end{abstract}

\title{
Sharon Zuckerman. The Pottery of Stratum 9 (the Persian Period)
}

\section{Astrid Nunn}

\section{OpenEdition}

1 Journals

Édition électronique

URL : http://journals.openedition.org/abstractairanica/41627

DOI : 10.4000/abstractairanica.41627

ISSN : 1961-960X

Éditeur :

CNRS (UMR 7528 Mondes iraniens et indiens), Éditions de l'IFRI

\section{Référence électronique}

Astrid Nunn, "Sharon Zuckerman. The Pottery of Stratum 9 (the Persian Period) 》, Abstracta Iranica [En ligne], Volume 34-35-36 | 2017, document 58, mis en ligne le 15 juillet 2016, consulté le 05 octobre 2020. URL : http://journals.openedition.org/abstractairanica/41627 ; DOI : https://doi.org/10.4000/ abstractairanica.41627

Ce document a été généré automatiquement le 5 octobre 2020.

Tous droits réservés 


\title{
Sharon Zuckerman. The Pottery of Stratum 9 (the Persian Period)
}

\author{
Astrid Nunn
}

\section{RÉFÉRENCE}

Sharon Zuckerman. « The Pottery of Stratum 9 (the Persian Period) », in : Alon de Groot, Hannah Bernick-Greenberg, Excavations at the City of David 1978-1985 directed by Yigal Shiloh, vol. VIIB: Area E: The Finds. 2012. (Qedem, 54)

1 Les publications sur Jérusalem traitent peu souvent de l'époque achéménide. Tel est le cas des deux volumes complémentaires présentés ici. L'Area E est une grande surface située au centre de la ville de David. Des 16 strates la state 9 a été datée de l'époque achéménide grâce à la céramique retrouvée partout. Une installation domestique n'a au contraire été reconnue que dans l'Area E West (vol. VIIA, 173-176). La céramique est présentée par S. Zuckerman dans le vol VIIB (p. 31-56). Les types de bols carénés, de vases, cratères, bouteilles, flacons, cruches, amphores et lampes correspondent tous aux types classifiés à l'époque achéménide. Il s'agit de vaisselle quotidienne. Toute vaisselle peinte ou importée manque.

Ce compte rendu concerne également une autre référence $\left(n^{\circ} 57\right)$ :

Alon De Groot, Hannah Bernick-Greenberg. Excavations at the City of David 1978-1985 directed by Yigal Shiloh, vol. VIIA: Area E: Stratigraphy and Architecture. Jerusalem, Institute of Archaeology, the Hebrew University of Jerusalem, 2012. (Qedem, 53) 


\section{AUTEURS}

\section{ASTRID NUNN}

Université de Munich 